\title{
Content of Total Phenols in Red Heart and Wound- Associated Wood in Beech (Fagus sylvarica L.)
}

\section{Sadržaj ukupnih fenola u crvenom srcu i ranjenom dijelu drva bukve (Fagus sylvatica L.)}

\author{
Original scientific paper • Izvorni znanstveni rad \\ Received-prispjelo: 31. 5. 2012. \\ Accepted-prihvaćeno: 15. 2. 2013. \\ UDK: $630 * 813.111 ; 674.031 .632 .224$ \\ doi:10.5552/drind.2013.1224
}

\begin{abstract}
The structure of wound-associated wood has been relatively well studied in beech, but only a little information about the occurrence of extractives and particular classes of compounds in these tissues is available. We examined the content of total phenols and variability in their distribution in sapwood, wound-wood and the reaction zones walling-off typical red heart and xylem altered by wounding in two beech trees, using spectrophotometric method. Significant differences in total phenols in different types of beech wood, as well as differences between trees, were confirmed. Concentrations of total phenols were markedly lower in red heart than in reaction zones and sapwood extracts. The content of total phenols was highest in extracts of the reaction zones formed as a direct response of sapwood to wounding. Differences in the content of total phenols in reaction zones walling-off typical red heart and directly wounded xylem indicate differences in their formation process, in alterations to surrounding tissues and in the characteristics of individual trees.
\end{abstract}

Keywords: phenols, spectrophotometry, reaction zone, Folin-Ciocalteu reagent, beech

SAŽETAK • Za drvo bukve relativno je dobro istražena struktura ranjenog drva, ali je dostupno malo informacija o pojavi određenih ekstraktiva i pojedinih klasa spojeva u tim tkivima. Primjenom spektrofotometrijske metode na dva smo bukova stabla istražili sadržaj ukupnih fenola i varijabilnost njihove raspodjele u drvu bijeljike, ranjenom drvu i reakcijskim zonama koje ograđuju tipična crvena srca i ksileme promijenjene zbog ranjavanja drva. Potvrđene su značajne razlike u ukupnim fenolima u različitim tipovima bukova drva, kao i razlike među stablima. Koncentracije ukupnih fenola znatno su niže u crvenom srcu nego u reakcijskim zonama i ekstraktima bjeljike. Sadržaj ukupnih fenola bio je najviši u ekstraktima reakcijskih zona formiranih kao izravan odgovor bjeljike na ranjavanje. Razlike u sadržaju ukupnih fenola u reakcijskim zonama koje ograđuju tipična crvena srca i izravno ranjen ksilem pokazuju razlike u procesu formiranja, u promjenama na okolnim tkivima i u obilježjima pojedinih stabala.

Ključne riječi: fenoli, spektrofotometrija, reakcijska zona, Folin-Ciocalteauov reagens, bukva

\footnotetext{
${ }^{1}$ Authors are assistant, professor and assistant professor at University of Ljubljana, Biotechnical Faculty, Department of Wood Science and Technology, Ljubljana, Slovenia.

Autori su asistent, profesor i docentica Biotehničkog fakulteta Sveučilišta u Ljubljani, Odjel za znanost o drvu i drvnu tehnologiju, Ljubljana, Slovenija.
} 


\section{INTRODUCTION}

\section{UVOD}

European beech (Fagus sylvatica L.) is an economically important tree species in Slovenian forests, where it represents approximately $31.8 \%$ of wood stock (Anonymus, 2011). The economic importance of beech has increased in recent years because of the continuous demand for bright and evenly colored grades of logs and sawn timber (Pöhler et al., 2006). However, the occurrence of red heart amongst older trees and the consequences of mechanical wounding to the lower parts of stems, which occurs during forestry operations in unevenly managed forests, decrease wood quality and even increase timber loss. Discolored beech wood has a lower value on the market today than unaffected wood, due to its unfavorable technological properties, including hard impregnation, problems in drying processes and veneer production and, finally, its esthetic deficiency (Koch et al., 2000; Pöhler et al., 2006).

Beech is therefore a tree species that develops discolored wood in the core of the stem, which is commonly referred to as red heart, red heartwood, facultatively colored heartwood, false heartwood or red core (Bosshard, 1974; Torelli, 1984; Shigo, 1986; Sachsse, 1991; Wernsdörfer et al., 2005). Typical red heart is located in the central part of the stem, it is reddish to brownish, rounded and uniform in color or of cloudy appearance in cross-section (Sachsse, 1991). The formation and extent of red heart can be explained by the characteristics of an individual tree: age, diameter, live crown ratio, presence of broken branches and characteristics of growth site (Torelli, 1984).

The lower parts of the stems of trees in unevenly managed forests are regularly wounded, due to the use of heavy mechanization during forestry and logging operations. Such injuries are usually superficial to the stem, meaning that the bark is usually peeled off from the wood. The surface of the xylem cylinder is thus exposed to atmospheric conditions. This kind of wounding triggers changes in the wood that is already being formed at the time of wounding and the formation of wound-wood (Shigo, 1986). Both processes can be satisfactorily explained by the compartmentalization concept (Shigo, 1986; Dujesiefken and Liese, 2006). In directly wounded stems, discoloration can be compartmentalized on the surface of the stem (Grosser et al., 1991) or can merge with the red heart, if present in the tree (Torelli, 2001). Wound-associated defects, as well as red heart, are walled off from sound sapwood by darker demarcations zones, called reaction zones (Shain, 1979; Schwarze and Baum, 2000).

The anatomy of discolored red heart, wound-associated discolored wood and reaction zones has been relatively well studied (Nečesany, 1958; Pearce, 1990; Schmitt and Liese, 1993; Torelli et al., 1994; Schwarze and Baum, 2000; Merela et al., 2005), but only a little information about the distribution and occurrence of extractives and particular classes of compounds in these tissues is available (Albert et al., 2003; Hofmann et al., 2008).
The aim of this study was to determine the content of total phenols by means of spectrophotometric analysis in the reaction zone of typical red heart and in tissues that are formed as a response of the wood to direct wounding.

\section{MATERIAL AND METHODS} 2. MATERIJAL I METODE

\subsection{Reagents}

2.1. Reagensi

Methanol of HPLC grade and Folin-Ciocalteu phenol reagent $(2 \mathrm{~N})$ were purchased from SigmaAldrich, sodium carbonate (anhydrous) was provided by Riedel-de Haën and gallic acid monohydrate, applied for calibration, was from Fluka.

\subsection{Material}

2.2. Materijal

Two mechanically wounded beech trees (Fagus sylvatica L.) growing on a gentle southwest slope of the urban forest of Rožnik in the City of Ljubljana were felled in February 2009. A diameter at breast height of tree No. 1 was $48 \mathrm{~cm}$ and of tree No. 2 it was $52 \mathrm{~cm}$. Both trees had an approximately $3 \mathrm{~m}$ long mechanical wound extending from the bottom of the tree.

One set of discs was sampled from the lower wounded area and a second set of discs was taken from the upper part of the trees. From the wounded part of the stems, four disks of approximately $10 \mathrm{~cm}$ in thickness were dissected at distances of $1.0 \mathrm{~m}, 2.0 \mathrm{~m}$ and 3.0 $\mathrm{m}$ above the ground. Another four disks were removed at $5.0 \mathrm{~m}, 10 \mathrm{~m}, 20 \mathrm{~m}$ and $25 \mathrm{~m}$ above the ground, along the upper part of the stems.

The discs were transferred to a woodworking facility for further mechanical processing. After visual inspection, discs from the first group were dissected in a uniform way so that samples of sapwood, discolored wood, reaction zones and wound-wood were obtained. Radial samples, extending from bark to bark were cut from the discs of the second group. After removing the bark, these samples were dissected by chisel and hammer to obtain up to 14 sample blocks of different categories of wood tissue, i.e., sapwood, reaction zones and discolored wood (red heart). Reaction zones were carefully separated from sapwood and discolored wood in all discs. A number of samples of wound-associated tissues were defined by extent of the wound and its consequences. In the case of reaction zones and woundwood, two samples were obtained per tissue. In each disk, 4-6 samples of sapwood and 2-4 samples of discolored wood were dissected. Only one sample of red heart was obtained in tree No. 2 from the disk at $25 \mathrm{~m}$ of height. A total of 157 wood samples were obtained from the two trees.

\subsection{Extraction}

2.3. Ekstrakcija

Individual samples were homogenized by the mill Retsch ZM 200, using a sieve with a 35 mesh screen. Milled wood was stored at minus $18{ }^{\circ} \mathrm{C}$ until further chemical analysis to prevent unwanted chemi- 
cal reactions. Phenolic compounds were extracted from $2.5 \mathrm{~g}$ of each sample by $80 \%$ methanol (aq) using a multi-position magnetic stirrer (IKA, RO 15) according to the protocol described by Albert et al. (2003). Wood extracts were filtered by Büchner funnel, Whatman GF-C filter paper and vacuum flask, and stored at minus $4{ }^{\circ} \mathrm{C}$ until further analysis.

\subsection{Estimation of the content of total phenols \\ 2.4. Procjena sadržaja ukupnih fenola}

Total phenol content was determined colorimetrically by means of the Folin-Ciocalteu method following the procedure proposed by Scalbert et al. (Singleton and Rossi, 1965; 1989).

A volume of $2.5 \mathrm{ml}$ of diluted Folin-Ciocalteu phenol reagent $(1: 9, \mathrm{v} / \mathrm{v})$ was added to $0.5 \mathrm{ml}$ of methanolic extracts and gallic acid solutions $(a q)$. Within a period of 0.5 to 8.0 minutes, $2 \mathrm{ml}$ of aqueous sodium carbonate $\left(75 \mathrm{~g} \cdot \mathrm{l}^{-1}\right)$ was added as well. The thus prepared samples were well shaken and incubated for two hours at room temperature. Absorbance was measured at 765 $\mathrm{nm}$ by Perkin-Elmer Lambda 2 spectrophotometer. Results were determined by standard curve with gallic acid $\left(0-200 \mathrm{mg}^{-1} \mathrm{-}^{-1}\right)$ and expressed as milligrams of gallic acid equivalents per gram of dry wood $\left(\mathrm{mg} \cdot \mathrm{g}_{\mathrm{dw}}{ }^{-1}\right)$.

\subsection{Statistics}

\subsection{Statistika}

Total phenol content of beech wood extracts was compared by statistical methods, where significant differences were investigated by means of ANOVA at 0.95 interval of confidence. The contents of total phenols for different categories of discolored and wounded wood tissue were further compared by means of the multiple range test (LSD procedure). The contribution of individual tissue to the variation of total phenols was estimated by variance components analysis. A statistical software Statgraphics was applied for statistical data processing.

\section{RESULTS}

\section{REZULTATI}

The total phenol content for different categories of wood is presented separately for the upper and lower groups of samples for tree No. 1 and tree No. 2. In samples from the upper part of the stems (Fig. 1), which were free of wounds, the content of total phenols was significantly different among categories of tissue (ANOVA, $P=0.0000$ ) and between trees (ANOVA, $P$ $=0.0003)($ Table 1$)$.
Table 1 Average content of total phenols $\left(\mathrm{mg} \cdot \mathrm{g}_{\mathrm{dw}}{ }^{-1} \pm\right.$ standard deviation) in sapwood and reactions zones surrounding red heart in the upper part of beech trees Tablica 1. Prosječni sadržaj ukupnih fenola $\left(\mathrm{mg} \cdot \mathrm{g}_{\mathrm{dw}}{ }^{-1} \pm\right.$ standardna devijacija) u bjeljici i reakcijskim zonama oko crvenog srca u gornjem dijelu bukovih stabala

\begin{tabular}{|c|c|c|c|}
\hline $\begin{array}{c}\text { Tree No. } \\
\text { Broj stabla }\end{array}$ & $\begin{array}{c}\text { Sapwood } \\
\text { Bjeljika } \\
\mathrm{mg} \cdot \mathrm{g}_{\mathrm{dw}}{ }^{-1}\end{array}$ & $\begin{array}{c}\text { Reaction zones } \\
\text { Reakcijske zone } \\
\mathrm{mg} \cdot \mathrm{g}_{\mathrm{dw}}{ }^{-1}\end{array}$ & $\begin{array}{c}\text { Red heart } \\
\text { Crveno srce } \\
\mathrm{mg} \cdot \mathrm{g}_{\mathrm{dw}}{ }^{-1}\end{array}$ \\
\hline 1 & $9.03 \pm 2.64^{\mathrm{a}}$ & $9.78 \pm 2.97^{\mathrm{b}}$ & $2.77 \pm 0.71^{\mathrm{c}}$ \\
\hline 2 & $6.75 \pm 2.62^{\mathrm{a}}$ & $5.62 \pm 1.41^{\mathrm{b}}$ & $1.78 \pm 0.32^{\mathrm{c}}$ \\
\hline
\end{tabular}

Values marked by a letter differ significantly at a $95 \%$ confidence level (LSD procedure) / vrijednosti označene slovom signifikantno se razlikuju pri razini vjerojatnosti $95 \%$.

The content of total phenols was significantly lower in red heart than in reaction zones and sapwood in both trees (Table 1). Reactions zones and sapwood did not differ in the content of total phenols at a $95 \%$ confidence level (LSD) in the investigated trees (Table 1). The content of total phenols was significantly higher in tree No. 1 than in tree No. 2 in all examined tissues (Table 1). Peripheral sapwood samples contained a significantly lower amount of total phenols (6.59 $\left.\mathrm{mg} \cdot \mathrm{g}^{-1}\right)$ than sapwood samples near red heart $\left(9.7 \mathrm{mg} \cdot \mathrm{g}^{-1}\right)$ at a $95 \%$ confidence level (LSD test) (Fig. 1). The average content of total phenols in samples from the upper part of tree No. 1 was $7.51 \mathrm{mg} \mathrm{g}^{-1}$ and $5.60 \mathrm{mg} \cdot \mathrm{g}^{-1}$ in tree No. 2. The contribution of wood tissue to the variation of total phenols was $43.82 \%$, whereas $17.34 \%$ was ascribed to between-tree variability. Differences in the content of total phenols among discs sampled along the trees were not significant (Fig. 2).

The distribution of the content of total phenols in samples containing wounds (lower part of the stems) is shown in Table 2 . In discs with mechanical wounds, the content of total phenols was significantly different among categories of tissue (ANOVA, $P=0.0000$ ), irrespective of the tree. A significant difference in the content of total phenols between trees was found for reaction zones (Table 2 ).

The average content of total phenols in the investigated samples of both trees was significantly different and was highest in reaction zones $\left(14.01 \mathrm{mg} \cdot \mathrm{g}^{-1} \mathrm{of}\right.$ absolutely dry wood), followed by sapwood $\left(9.12 \mathrm{mg} \cdot \mathrm{g}^{-1}\right)$ and wound-wood $\left(6.78 \mathrm{mg} \cdot \mathrm{g}^{-1}\right)$. Wound-associated discolored wood was present only in tree No. 2 and contained $1.78 \mathrm{mg}$ of total phenols per $1 \mathrm{~g}$ of absolutely dry wood. The content of total phenols in different categories of tissue accounts for $51.32 \%$ of its variability.

Table 2 Average content of total phenols ( $\mathrm{mg} \mathrm{g}_{\mathrm{dw}}{ }^{-1} \pm$ standard deviation) in different categories of tissue from the wounded part of stems

Tablica 3. Prosječni sadržaj ukupnih fenola $\left(\mathrm{mg} \cdot \mathrm{g}_{\mathrm{dw}}{ }^{-1} \pm\right.$ standardna devijacija) u različitim kategorijama tkiva od ranjenih dijelova debla

\begin{tabular}{|c|c|c|c|c|}
\hline $\begin{array}{c}\text { Tree No. } \\
\text { Broj stabla }\end{array}$ & $\begin{array}{c}\text { Sapwood / Bjeljika } \\
\mathrm{mg} \cdot \mathrm{g}_{\mathrm{dw}}{ }^{-1}\end{array}$ & $\begin{array}{c}\text { Wound-wood } \\
\text { Ranjeno drvo } \\
\mathrm{mg} \cdot \mathrm{g}_{\mathrm{dw}}{ }^{-1}\end{array}$ & $\begin{array}{c}\text { Reaction zones } \\
\text { Reakcijske zone } \\
\mathrm{mg} \cdot \mathrm{g}_{\mathrm{dw}}{ }^{-1}\end{array}$ & $\begin{array}{c}\text { Discolored wood } \\
\text { Drvo promijenjene boje } \\
\mathrm{mg}^{-\mathrm{g}_{\mathrm{dw}}}{ }^{-1}\end{array}$ \\
\hline 1 & $9.96 \pm 3.42$ & $6.79 \pm 2.62$ & $17.31 \pm 1.43^{\mathrm{a}}$ & $/$ \\
\hline 2 & $8.00 \pm 2.33$ & $6.77 \pm 3.31$ & $11.27 \pm 2.73^{\mathrm{a}}$ & $1.22 \pm 0.37$ \\
\hline
\end{tabular}

Values marked by a letter differ significantly at a 95\% confidence level (LSD procedure) /vrijednosti označene slovom signifikantno se razlikuju pri razini vjerojatnosti $95 \%$. 

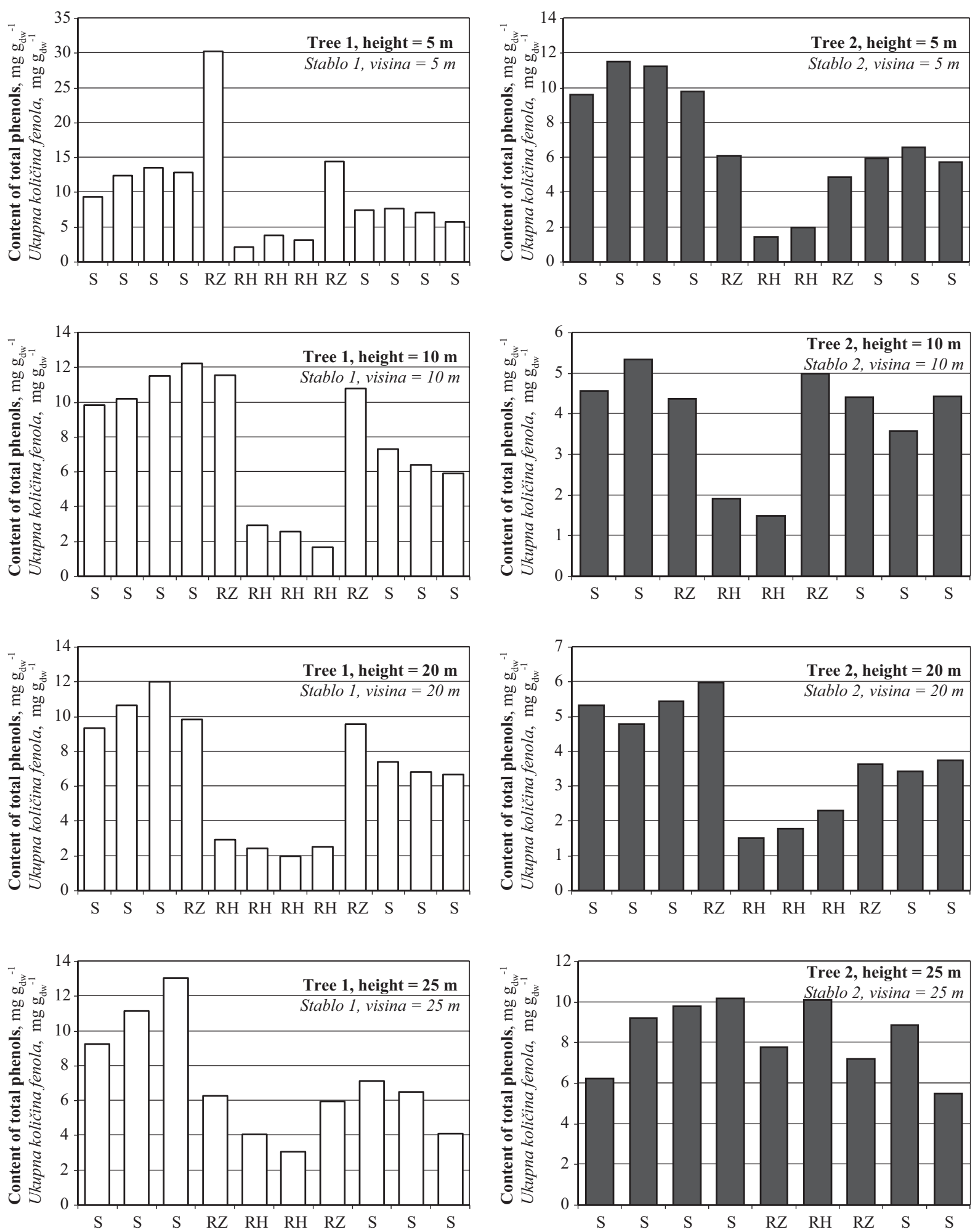

Figure 1 Radial profiles of the content of total phenols in sapwood (S), red heart (RH) and surrounding reaction zones (RZ) from the upper part of investigated beech stems

Slika 1. Radijalni profil sadržaja ukupnih fenola u bjeljici (S), crvenom srcu (RH) i okolnom reakcijskom drvu (RZ) od gornjeg dijela istraživanih bukovih debala

The average content of total phenols in reaction zones surrounding red heart (upper part of stems) was significantly lower than the content of phenols in reaction zones formed in the vicinity of the mechanical wound in the lower part of both stems (ANOVA, $P=0.0000$ ) (Table 1,2$)$. The position of the reaction zone within the tree accounts for $58 \%$ of the variability in the content of total phenols.

\section{DISCUSSION}

\section{RASPRAVA}

Our investigation revealed considerable variation in the content of total phenols in various wood tissues that had been altered by indirect or direct wounding and expands our understanding of the character of compartmentalization processes in beech. 
Vek, Oven, Poljanšek: Content of Total Phenols in Red Heart and Wound-Associated...
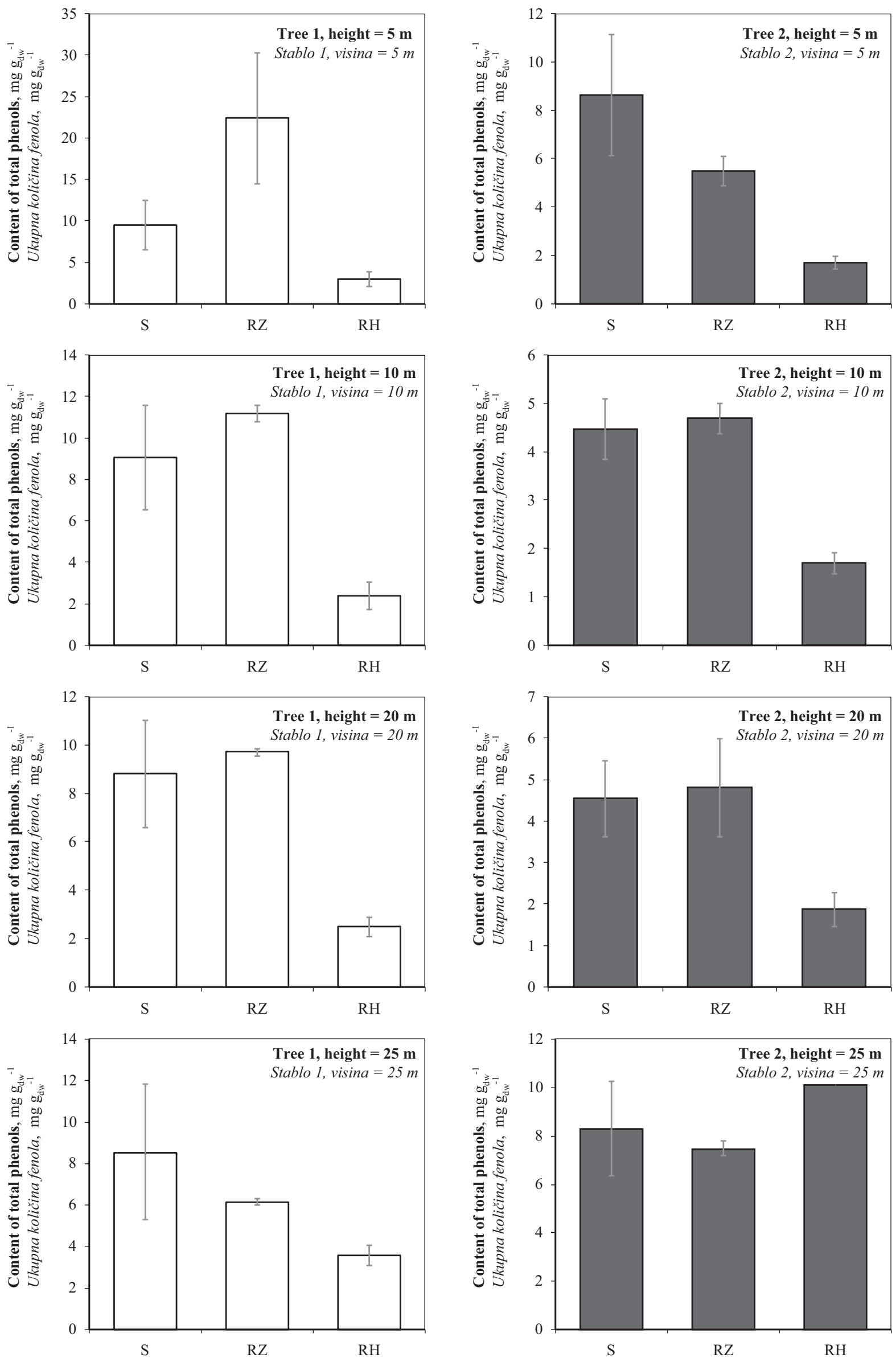

Figure 2 Average content of total phenols in red heart (RH), reaction zone (RZ) and sapwood (S) at different heights of investigated beech trees

Slika 2. Prosječni sadržaj ukupnih fenola u crvenom srcu (RH), reakcijskoj zoni (RZ) i bjeljici (S) na različitim visinama istraživanih bukovih stabala 


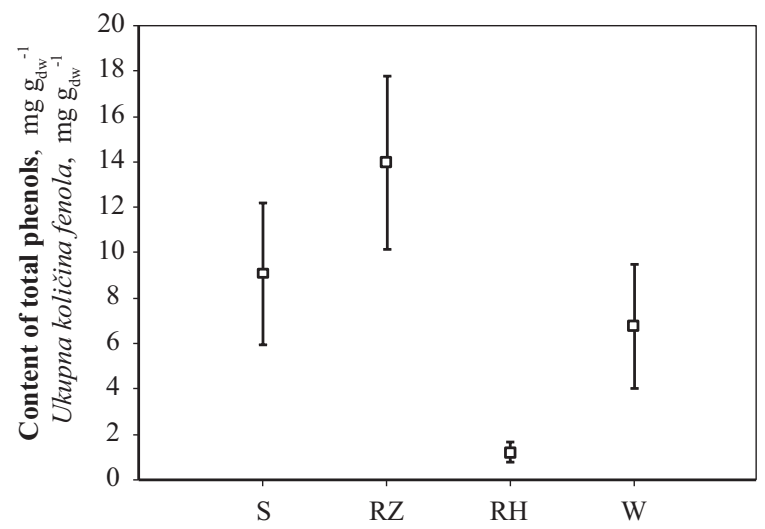

Figure 3 Average content of total phenols, supplemented by standard deviations, in different categories of wood tissues of directly wounded stems for two investigated trees. $\mathrm{S}=$ sapwood, $\mathrm{RZ}=$ reaction zone, $\mathrm{RH}=$ red heart, $\mathrm{W}=$ wound-wood

Slika 3. Prosječni sadržaj ukupnih fenola $\left(\mathrm{mg} \cdot \mathrm{g}_{\mathrm{dw}}{ }^{-1} \pm\right.$ standardna devijacija) u različitim kategorijama tkiva izravno ranjenih dijelova debla za dva istraživana stabla: $\mathrm{S}$ - bjeljika, $\mathrm{RZ}$ - reakcijska zona, $\mathrm{RH}$ - crveno srce, $\mathrm{W}$ - ranjeno drvo

The content of total phenols of the group of samples with red heart differed more than samples that had been directly wounded. The content of total phenols in sapwood was higher than in red heart, whereas reaction zones and sapwood did not differ in this respect. The concentration of total phenols shows a rising trend from the peripheral towards the inner parts of sapwood, which supports the observations of Albert et al. (2003). They found a steep increase in the content of total phenols in white tissue, just before the red heartwood boundary and a sharp drop in the content of phenols in the tissues that correspond to the color-boundary (Albert et al., 2003). White tissue, referred to as the dehydrated zone (Torelli, 1984) or transition zone (Hillis, 1987), was not distinguishable in our fresh discs and was therefore not dissected for extractions. It has been reported that the occurrence of this zone in Fagus sylvatica may have a seasonal character (Hillis, 1987). The occurrence of phenolics in sapwood of beech is in accordance with a report that flavan-3-ols, substances of a leucocyainidn type, taxifolin derivatives and proanthocyanidins are regularly present in sapwood (Dietrichs, 1964; Baum and Schwarze, 2002; Koch et al., 2003; Hofmann et al., 2004).

Typically, the discolored red heart of the investigated samples had the lowest amount of methanol soluble compounds, whereas the concentration of total phenolics increased abruptly in the peripheral tissues of red heart. This tissue was a clearly visible layer, referred to as the reaction zone (Shain, 1979; Pearce, 1996; Schwarze and Baum, 2000) or column boundary layer, which separates discolored wood from healthy sapwood (Shortle and Smith, 1990). The content of total phenols in the reaction zones surrounding the red heart of our samples was in contrast to the concentrations of total phenols determined at the color boundary by Albert et al. (2003). It has been suggested that in red heart-wooded beech, part of the phenols form in situ in the white tissue next to the color boundary, whereas their partici- pation in the formation of colored materials via oxidation and polymerization explains the drop in concentration of total phenols behind the color-boundary and the low content in the red heart (Albert et al., 2003).

The results of spectrophotometric analysis showed significant differences with regard to the quantity of soluble phenolic compounds in reaction zones surrounding typical red heart and those reaction zones associated with direct wounding of the stems. The almost two times higher concentration of soluble phenols in reaction zones associated with direct wounding supports the idea that these compartmentalization boundaries differ, among other things, in terms of their formation process (Baum and Schwarze, 2002) and alterations in adjacent discolored wood (Shortle and Smith, 1990; Shortle et al., 1995).

The formation of typical red heart can be described as a two stage process (Torelli, 2003). The first stage is a dehydrating phase, characterized by age-related and physiological alterations of the wood, which include a decrease in water content, increase in the presence of gas and decrease in the vitality of the parenchyma cells. The second stage is the discoloring phase, which is decidedly facultative, depending on the potential entry of oxygen into the already existing dehydrated core (Torelli, 1984). Dead and broken branches, branch scars, forks or wounds in the crown are possible routes for oxygen entrance (Torelli, 1984; Wernsdörfer et al., 2005). It is assumed, however, that oxygen is not the only factor involved in red heart formation but could act by affecting the activity of microorganisms (Sorz and Hietz, 2008).

Superficial wounding of the stem differs from the above described red heart formation in that direct wounding affects water saturated xylem containing vital parenchyma cells. Investigation of angiosperm species revealed that wounding triggers an initial physical dehydration of the wood, followed by a series of turbulent micro-environmental, anatomical and chemical changes, resulting in the formation of superficial discolored wood surrounded by apparent reaction zones (Grosser et al., 1991; Pearce et al., 1994; Barry et al., 2000; Pearce, 2000; Schwarze and Baum, 2000; Oven et al., 2008). Our results in relation to the content of total phenols show that reaction zones associated with wounds walled-off already decaying wood and exhibit a higher soluble phenol content, whereas reaction zones surrounding red heart revealed a lower phenol content. Our observations are in accordance with investigations on the response of Acer rubrum and Acer saccharum to wounding, revealing that a distinct boundary layer formed between sapwood and discolored wood infected by microorganisms, suggesting that the boundary layer may be formed only in response to infection (Shortle et al., 1995).

\section{CONCLUSIONS 5. ZAKLJUČCl}

Our research confirmed significant differences in total phenols in different types of beech wood, as well 
as differences between trees. Concentrations of total phenols were markedly lower in red heart than in reaction zones and sapwood extracts. The content of total phenolics was highest in extracts of the reaction zone, especially in those that had been formed as a direct response of tissues to wounding. Relatively high amounts of polyphenols were found in sapwood extracts, whereas the content of total phenols was higher in older than in younger parts of sapwood. It should be stressed in conclusion that reaction zones in beech appear to be effective but not absolute compartmentalization boundaries (Schwarze and Baum, 2000). Their efficacy may be in part ascribed to individual phenolic compounds. Hydrophilic extractives from wound-associated wood of beech (Fagus sylvatica L.) could represent attractive substances for industrial production. Our recent research showed that extracts of wound-associated wood of beech inhibited the growth of some wood decaying fungi (Vek et al., 2013) and, therefore, might be utilized as wood preservatives. It was also proven that some wood extractives have antioxidative properties (Pietarinen et al., 2006) and can potentially be used as technical antioxidants. Our further research is directed towards identification and quantification of compounds in extracts of wound-associated wood of beech.

\section{Acknowledgement - Zahvala}

The authors would like to thank the Slovenian Research Agency for financial support within the framework of research program P4-0015-0481.

\section{REFERENCES}

\section{LITERATURA}

1. Albert, L.; Hofmann, T.; Nemeth, Z. I.; Retfalvi, T.; Koloszar, J.; Varga, S.; Csepregi, I., 2003: Radial variation of total phenol content in beech (Fagus sylvatica L.) wood with and without red heartwood. Holz als Roh- und Werkstoff, 61 (3): 227-230.

2. Anonymus, 2011: Poročilo Zavoda za gozdove Slovenije o gozdovih za leto 2010. Ljubljana, Zavod za gozdove Slovenije.

3. Barry, K. M.; Pearce, R. B.; Mohammed, C. M., 2000: Properties of reaction zones associated with decay from pruning wounds in plantation-grown Eucalyptus nitens. Forest Pathol., 30 (5): 233-245

http://dx.doi.org/10.1046/j.1439-0329.2000.00206.x.

4. Baum, S.; Schwarze, F., 2002: Large-leaved lime (Tilia platyphyllos) has a low ability to compartmentalize decay fungi via reaction zone formation. New Phytologist, 154 (2): 481-490 http://dx.doi.org/10.1046/j.1469-8137.2002.00390.x.

5. Bosshard, H. H., 1974: Holzkunde. Band 2. Zur Bilogie, Physic und Chemie des Holzes., Basel, Stutgart, Birkhäuser Verlag.

6. Dietrichs, H. H., 1964: Chemisch-physilogische Untersuchungen über die Splint-Kern-Umwandlung der Rotbuche (Fagus sylvatica L.) - Ein Beitrag zur Frage der Holzverkernung. Mitteilungen der BFH 58.

7. Dujesiefken, D.; Liese, W., 2006: Die Wundreaktionen von Bäumen - CODIT haute. In: Dujesiefken D., Kockerbeck P. (Eds): Jahrbuch der Baumpflege 2006. Braunschweig, Thalacker Medien, pp. 21-40.
8. Grosser, D.; Lesnino, G.; Schulz, H., 1991: Histologische Untersuchungen über das Schutzholz einheimischer Laubbäume. Eur. J. Wood Prod., 49 (2): 65-73 http://dx.doi.org/10.1007/BF02662804.

9. Hillis, W. E., 1987: Heartwood and tree exudates. BerlinNew York, Springer-Verlag http://dx.doi.org/10.1007/978-3-642-72534-0.

10. Hofmann, T.; Albert, L.; Retfalvi, T., 2004: Quantitative TLC analysis of (+)-catechin and (-)-epicatechin from Fagus sylvatica L. with and without red heartwood. Journal of Planar Chromatography, 17: 350-354 http://dx.doi.org/10.1556/JPC.17.2004.5.5.

11. Hofmann, T.; Albert, L.; Retfalvi, T.; Visi-Rajczi, E.; Brolly, G., 2008: TLC analysis of the in-vitro reaction of beech (Fagus sylvatica L.) wood enzyme extract with catechins. Journal of Planar Chromatography, 21 (2): 83-88 http://dx.doi.org/10.1556/JPC.21.2008.2.2.

12. Koch, G.; Bauch, J.; Puls, J.; Schwab, E.; Welling, J., 2000: Vorbeugung gegen verfärbungen von rotbuche. Holz-Zentralblatt, 126: 74-75.

13. Koch, G.; Puls, J.; Bauch, J., 2003: Topochemical characterisation of phenolic extractives in discoloured beechwood (Fagus sylvatica L.). Holzforschung, 57 (4): 339-345 http://dx.doi.org/10.1515/HF.2003.051.

14. Merela, M.; Straže, A.; Zupančič, M.; Torelli, N.; Oven, P., 2005: Osnovna gostota, permeabilnost in zgradba reakcijskih con pri bukvi. Les, 57 (1-2): 11-16.

15. Nečesany, V., 1958: Jadro buku. Struktura, vznilka vyvyoj. Bratislava, Slovenskej Akademie Vied.

16. Oven, P.; Merela, M.; Mikac, U.; Sersa, I., 2008: 3D magnetic resonance microscopy of a wounded beech branch. Holzforschung, 62 (3): 322-328 http://dx.doi.org/10.1515/HF.2008.022.

17. Pearce, R. B., 1990: Occurrence of decay-associated xylem suberization in a range of woody species. European Journal of Forest Pathology, 20 (5): 275-289 http://dx.doi.org/10.1111/j.1439-0329.1990.tb01140.x.

18. Pearce, R. B., 1996: Antimicrobial defences in the wood of living trees. New Phytologist, 132 (2): 203-233 http://dx.doi.org/10.1111/j.1469-8137.1996.tb01842.x.

19. Pearce, R. B., 2000: Decay development and its restriction in trees. Journal of Arboriculture, 26 (1): 1-11.

20. Pearce, R. B.; Sumer, S.; Doran, S. J.; Carpenter, T. A.; Hall, L. D., 1994: Non-invasive imaging of fungal colonization and host response in the living sapwood of sycamore (Acer pseudoplatanus L.) Using Nuclear-MagneticResonance. Physiol. Mol. Plant Pathol., 45 (5): 359-384 http://dx.doi.org/10.1016/S0885-5765(05)80065-7.

21. Pietarinen, S.; Willför, S.; Ahotupa, M.; Hemming, J.; Holmbom, B., 2006: Knotwood and bark extracts: strong antioxidants from waste materials. Journal of Wood Science, 52 (5): 436-444 http://dx.doi.org/10.1007/s10086-005-0780-1.

22. Pöhler, E.; Klingner, R.; Kunniger, T., 2006: Beech ( $F a-$ gus sylvatica L.) - Technological properties, adhesion behaviour and colour stability with and without coatings of the red heartwood. Ann. For. Sci., 63 (2): 129-137 http://dx.doi.org/10.1051/forest:2005105.

23. Sachsse, H., 1991: Kerntypen der Rotbuche. Forstarchiv, (62): 238-242.

24. Scalbert, A.; Monties, B.; Janin, G., 1989: Tannins in wood: Comparison of different estimation methods. J. Agric. Food Chem., 37 (5): 1324-1329 http://dx.doi.org/10.1021/jf00089a026.

25. Schmitt, U.; Liese, W., 1993: Response of xylem parenchyma by suberization in some hardwoods after mechanical injury. Trees - Structure and Function, 8 (1): 23-30. 
26. Schwarze, F. W. M. R.; Baum, S., 2000: Mechanisms of reaction zone penetration by decay fungi in wood of beech (Fagus sylvatica). New Phytologist, 146 (1): 129-140 http://dx.doi.org/10.1046/j.1469-8137.2000.00624.x.

27. Shain, L., 1979: Dynamic responses of differentiated sapwood to injury and infection. USA, American Phytopathological Society: Symposium on wood decay in living trees, 69 (10): 1143-1147.

28. Shigo, A. L., 1986: A new tree biology - Dictionary. Durham, New Hamshire, Shigo and Trees Associates.

29. Shortle, W. C.; Smith, K. T., 1990: Decay column boundary layer formation in maple. Biodegradation Research, 3: 377-389.

30. Shortle, W. C.; Smith, K. T.; Dudzik, K. R.; Parker, S., 1995: Response of maple sapwood to injury and infection. European Journal of Forest Pathology, 25 (5): 241-252 http://dx.doi.org/10.1111/j.1439-0329.1995.tb01009.x.

31. Singleton, V. L.; Rossi, J. A., Jr., 1965: Colorimetry of total phenolics with phosphomolybdic-phosphotungstic acid reagents. American Journal of Enology and Viticulture, 16 (3): 144-158.

32. Sorz, J.; Hietz, P., 2008: Is oxygen involved in beech (Fagus sylvatica) red heartwood formation? Trees Structure and Function, 22 (2): 175-185.

33. Torelli, N., 1984: The ecology of discolored wood as illustrated by beech (Fagus sylvatica L.). IAWA Bulletin, 5 (2): 121-127.

34. Torelli, N., 2001: Odziv drevja na globoke in površinske poškodbe na primeru bukve (Fagus sylvatica L.) s poudarkom na nastanku in ekologiji ranitvenega lesa ("rdeče srce"). Pregled $=$ Response of trees on deep and superficial wounds as illustrated by beech (Fagus sylvatica L.) with particular emphasis on aetiology and ecology of wound initiated discoloured wood ("red hearth"). A review. Gozdarski vestnik, 59 (2): 85-94.

35. Torelli, N., 2003: Ojedritev - vloga in proces. Les, 55: 368-379.

36. Torelli, N.; Križaj, B.; Oven, P., 1994: Barrier zone (CODIT) and wound-associated wood in beech (Fagus sylvatica L.). Holzforschung und Holzverwertung, 46 (3): 49-51.

37. Vek, V.; Oven, P.; Humar, M., 2013: Phenolic extractives of wound-associated wood of beech and their fungicidal effect. International Biodeterioration \& Biodegradation, 77 (0): 91-97. In press http://dx.doi.org/10.1016/j.ibiod.2012.10.013.

38. Wernsdörfer, H.; Constant, T.; Mothe, F.; Badia, M. A.; Nepveu, G.; Seeling, U., 2005: Detailed analysis of the geometric relationship between external traits and the shape of red heartwood in beech trees (Fagus sylvatica L.). Trees, 19 (4): 482-491 http://dx.doi.org/10.1007/s00468-005-0410-y.

\section{Corresponding address:}

Professor PRIMOŽ OVEN, Ph.D.

University of Ljubljana, Biotechnical faculty Department of wood science and technology Rožna dolina, Cesta VIII/34

Si-1000 Ljubljana

SLOVENIA

e-mail: primoz.oven@bf.uni-lj.si 